KONSELING: Jurnal Ilmiah Bimbingan dan Konseling

Vol.1, No.2, Januari 2020, pp. 67-73

e-ISSN: 2686-2875

https://journal.ilininstitute.com/konseling

DOI: https://doi.org/10.31960/konseling.v1i2.328

Received on 29/10/2019; Revised on 20/12/2019; Accepted on 15/01/2020; Published on:28/01/2020

\title{
Pengaruh Layanan Informasi dengan Media Audio Visual Terhadap Kreativitas Belajar
} Siswa

\author{
Bagus Pradikta \\ Bimbingan dan Konseling, Universitas PGRI Semarang, Indonesia \\ Corresponding author, E-mail: baguspradikta1992@gmail.com
}

\begin{abstract}
Abstrak. Tujuan penelitian untuk mengetahui peningkatan kreativitas belajar siswa melalui layanan informasi dengan menggunakan media audio visual. Jenis penelitian adalah kuantitatif. Data dalam penelitian diperoleh melalui instrument penelitian skala kreativitas belajar siswa dengan empat alternatif jawaban. Desain penelitian yang digunakan adalah Pretest-Posttest Control Group Design. Uji validitas instrumen penelitian menggunakan rumus Product Moment, dan dilanjutkan uji reliabilitas menggunakan rumus Alpha. Hasil uji validitas instrument diperoleh butir instrument yang valid 30 butir dan 10 butir tidak valid dengan koefisien reliabilitas sebesar 0,329. Berdasarkan hasil analisis data penelitian setelah mendapatkan perlakuan layanan informasi dengan media audio visual, menunjukkan adanya peningkatan kreativitas belajar siswa kelas XII melalui layanan informasi dengan media audio visual. Dari hasil pengajuan hipotesis menggunakan rumus $t$-test diperoleh $t_{\text {hitung }}$ sebesar 2,63 sementara $t_{\text {tabel }}$ dengan taraf signifikan 5\% $(0,05)$ sebesar 2,04 . Karena $t_{\text {hitung }} 2,63$ $>t_{\text {tabel }} 2,04$, maka dapat disimpulkan bahwa "layanan informasi dengan media audio visual berpengaruh terhadap kreativitas belajar pada siswa kelas XII SMA Kartika III1". Dari hasil penelitian ini disarankan kepada guru pembimbing hendaknya perlu memprogramkan secara sistematis layanan informasi dengan media audio visual agar siswa dapat meningkatkan kreativitas belajar.
\end{abstract}

Kata Kunci: Layanan Informasi, audio visual, Kreativitas belajar siswa

\begin{abstract}
The research objective is to find out the improvement of students' learning creativity through information services using audio visual media. This type of research is quantitative. The data in this study were obtained through a research instrument of student learning creativity scale with four alternative answers. The research design used was Pretest-Posttest Control Group Design. Test the validity of the research instruments using the Product Moment formula, and continued the reliability test using the Alpha formula. The instrument validity test results obtained 30 valid and 10 invalid instrument items with a reliability coefficient of 0.329 . Based on the results of the analysis of research data after getting information service treatment with audio visual media, it shows an increase in students' creativity in class XII through information services with audio visual media. From the results of submitting a hypothesis using the $\mathrm{t}$-test formula obtained 『t _ $_{-}$(count) of 2.63 while $t_{-}$(table) with a significant level of $5 \%$ (0.05) of 2.04. Because $t_{-}$(count) $2.63>\llbracket t \rrbracket$ _ (table) 2.04 , it can be concluded that "information services with audio visual media influence learning creativity in class XII students of Kartika III-1 High School". From the results of this study it is suggested that the supervising teacher should systematically program information services with audio-visual media so that students can increase learning creativity.
\end{abstract}

Keywoard: Information services, audio visual, student learning creativity 


\section{Pendahuluan}

Kreativitas merupakan salah satu fungsi dan tujuan pendidikan nasional yang terdapat dalam Undang-Undang Republik Indonesia Nomor 20 tahun 2003 tentang Sistem Pendidikan Nasional. Penjelasan ini lebih lanjut terdapat pada Bab II pasal 3 yang menyatakan bahwa pendidikan nasional berfungsi mengembangkan kemampuan dan membentuk individu menjadi beriman dan bertakwa kepada Tuhan Yang Maha Esa, berakhlak mulia, sehat, berilmu, kreatif, mandiri dan menjadi warga negara yang bertanggung jawab. Indonesia sebagai negara berkembang memerlukan individu yang kreatif sebagaimana terdapat pada fungsi dan tujuan pendidikan nasional yang telah disebut di atas. Rendahnya kreativitas nampak dalam berbagai bidang kehidupan masyarakat seperti bidang pendidikan dan ilmu pengetahuan. Dalam bidang pendidikan banyak individu menunjukan kecenderungan tidak mau berpikir berbeda dari kebiasaan pada orang umumnya, dan mengejar pendidikan formal yang lebih tinggi daripada menjadi seorang pemikir orisinal yang bebas berkreasi (Nur'aeni, 2008: 2). Dalam ilmu pengetahuan individu kreatif sangat berpengaruh karena setiap waktu itu berbeda sehingga individu harus berkreatif untuk mendapatkan ilmu pengetahuan yang baru.

Berdasarkan pendapat Nur'aeni (2008: 2) kreativitas sangat penting bagi kehidupan manusia. Kreativitas diperlukan untuk mengatasi berbagai kesulitan, mencari jalan keluar dari segala permasalahan yang dihadapi dan untuk meraih cita-cita yang didambakan. Tanpa kreativitas, seseorang akan sering terbentur kebuntuan dan itu jelas akan menghambat, bahkan akan mengurangi semangat berprestasi. Dengan kreativitas seseorang dapat mewujudkan dirinya, akan lancar dan luwes dalam berpikir, dapat melihat masalah dari berbagai sudut pandang, serta mampu melahirkan banyak gagasan. Kreativitas juga diperlukan untuk meningkatkan kualitas hidup seseorang .

Kreativitas adalah kemampuan unuk mencipta atau berkreasi. Keluwesan yang pada umumnya mengacu pada kemampuan untuk menemukan gagasan yang berbeda-beda dan luar biasa untuk memecahkan masalah (Nur'aeni, 2008: 2). Dalam proses belajar, kreativitas sangat penting untuk diterapkan. Menurut teori belajar adalah perubahan tingkah laku sebagai akibat dari adanya interaksi antara stimulus dan respon. Dengan kata lain, belajar merupakan bentuk perubahan yang di alami siswa dalam hal kemampuannya untuk bertingkah laku dengan cara yang baru sebagai hasil interaksi antara stimulus dan respon (Budiningsih, 2005:20).

Salah satu upaya untuk meningkatkan kreativitas belajar dapat dilakukan dengan cara melaksanakan layanan bimbingan. Oleh karena itu peranan sekolah termasuk guru BK sangat menentukan untuk memberikan cara-cara agar siswa lebih kreatif dalam belajarnya dan mampu menciptakan sesuatu yang baru untuk belajarnya sehingga hasil yang diperoleh memuaskan.

Natawidjaja (dalam Yusuf, 2011: 6) mengartikan bimbingan sebagai suatu proses pemberian bantuan kepada siswa yang dilakukan secara berkesinambungan, supaya siswa tersebut dapat memahami dirinya sendiri, sehingga dia sanggup mengarahkan dirinya dan dapat bertindak sewajarnya sesuai tuntutan keadaan lingkungan sekolah, keluarga, masyarakat dan kehidupan umumnya. Membantu siswa memiliki pemahaman terhadap dirinya sehingga siswa diharapkan mampu mengembangkan potensi dirinya secara optimal dan menyesuaikan dirinya dengan lingkungan secara dinamis dan kreatif.

Agar bimbingan itu berjalan dengan baik dan mudah diterima oleh siswa diberikan dalam bentuk layanan. Dalam proses bimbingan ada beberapa layanan salah satunya adalah layanan informasi. Layanan ini diberikan untuk memberikan informasi tentang pemecahan masalah yang dialami oleh siswa.

Layanan informasi merupakan suatu layanan yang diberikan kepada siswa untuk membekali siswa dengan berbagai pengetahuan tentang lingkungan yang diperlukan untuk memecahkan masalah yang dihadapi berkenaan dengan lingkungan pendidikan (Winkel, 2004: 317). Layanan informasi akan dapat menunjang pelaksanaan yang berkaitan antara bahan-bahan informasi itu dengan permasalahan siswa. Dalam hal ini akan diberikan jenis layanan informasi tentang pendidikan karena individu yang berstatus siswa dihadapkan pada kemungkinan timbulnya masalah atau kesulitan. Diantara masalah atau kesulitan tersebut berhubungan dengan belajarnya, penyesuaian diri dengan mata pelajaran, penyesuaian diri terhadap suasana belajar. Mereka 
membutuhkan adanya keterangan atau informasi untuk dapat membuat pilihan dan keputusan secara bijaksana (Prayitno dan Amti, 2013: 261).

Dalam memberikan layanan informasi biasanya siswa akan merasakan jenuh atau bosan dengan penyampaian informasi secara verbal hal ini akan menyebabkan informasi yang disampaikan tidak bisa diterima oleh siswa. Agar materi yang dibahas itu dapat dipahami oleh siswa yang pada giliranya masalah siswa terpecahkan atau siswa dapat mencapai tugas perkembangan dengan baik maka dibutuhkan media. Miarso (dalam Nursalim, 2013: 5) menyatakan media adalah segala sesuatu yang dapat digunakan untuk menyalurkan pesan yang dapat merangsang pikiran, perasaan, perhatian dan kemauan siswa belajar.

Media sebagai alat bantu dalam proses belajar mengajar adalah suatu kenyataan yang tidak dapat dipungkiri karena memang gurulah yang menghendakinya untuk membantu tugas guru dalam menyampaikan pesan-pesan dari bahan materi yang disampaikan oleh guru kepada anak didik. Guru sadar bahwa tanpa bantuan media , maka bahan pelajaran sukar untuk dicerna dan dipahami oleh setiap anak didik, terutama bahan materi yang rumit atau kompleks. Dalam layanan informasi menggunakan media adalah segala sesuatu yang dapat digunakan untuk menyalurkan pesan yang dapat merangsang pikiran, perasaan, perhatian dan kemauan siswa atau konseli utuk memahami diri, mengarahkan diri, mengambil keputusan serta memecahkan masalah yang dihadapi (Nursalim, 2013: 6). Ada beberapa media yang bisa membantu dalam layanan salah satunya adalah media audio visual karena media ini mempunyai unsur gambar dan suara yang menjadi daya tarik itu sendiri sehingga siswa akan memperhatikan dan mudah memahami pesan yang disampaikan melalui media audio visual ini.

Djamarah (2013: 124) mendefinisikan media audio visual adalah media yang mempunyai unsur suara dan unsur gambar. Media audio visual ini mempunyai nilai tertentu, yaitu dapat menarik dan memotivasi belajar siswa untuk mempelajarai materi lebih banyak, memancing inspirasi baru dan penyajian lebih menarik karena mengandung nilai rekreasi. Berdasarkan pendapat Setiyani (2013: 72) media audio visual untuk menunjang pembelajaran pada materi dalam meningkatkan pemahaman dikarenakan dengan media audio visual akan menjadikan penyajian bahan ajar kepada siswa semakin lengkap dan optimal.

\section{Metode}

Penelitian ini menggunakan metode penelitian true experimental design dengan bentuk randomized control-group presest-posttest control group desaign. Suryabrata $(2013,105)$ menjelaskan desain prosedur yang dilakukan dalam penelitian pengaruh kreativitas belajar menggunakan layanan informasi dengan media audio visual. Metode pengumpulan data dan alat pengumpulan data yang digunakan dalam penelitian ini adalah skala sikap yang didasarkan kepada data yang ingin diungkap yaitu kreativitas belajar.

\section{Hasil Dan Pembahasan}

Dengan variabel bebas atau layanan informasi dengan media audio visual yang dilambangkan dengan huruf $X$ dan variabel terikat atau kreativitas belajar siswa yang dilambangkan dengan huruf Y. Penelitian ini menggunakan metode true experiment dengan rancangan penelitian Pretest-Posttest Control Group Design.

Tabel 1 menunjukkan hasil pre-test skala kreativitas belajar menunjukkan bahwa seluruh siswa berada pada kelas interval 53-75 yaitu sebanyak 14 siswa yang termasuk dalam kategori rendah. Apabila dilihat dari hasil rata-rata skor pre-test skala kreativitas belajar pada kelas eksperimen sebesar 84,86 sedangkan pada kelas kontrol sebesar 82,77. Maka dapat disimpulkan bahwa secara keseluruhan hasil pre-test skala kreativitas belajar siswa kelas XII SMA Kartika III-1 Banyubiru berada pada kategori tinggi. 
KONSELING: Jurnal Ilmiah Bimbingan dan Konseling

Vol.1, No.2, Januari 2020

Available online: https://journal.ilininstitute.com/konseling

Bagus Pradikta

Tabel 1. Distribusi Frekuensi Hasil Pre-test

\begin{tabular}{lllllll}
\hline \multicolumn{2}{c}{ Kontrol } & \multirow{2}{*}{ Interval } & Kategori & Interval & \multicolumn{2}{c}{ Eksperimen } \\
\cline { 1 - 1 } Presentase & Frekuensi & & & & Frekuensi & Presentase \\
\hline $0 \%$ & 0 & $99-120$ & Sangat & $99-120$ & 2 & $6 \%$ \\
$76 \%$ & 26 & $76-98$ & Tinggi & $76-98$ & 27 & $77 \%$ \\
$24 \%$ & 8 & $53-75$ & Rendah & $53-75$ & 6 & $17 \%$ \\
$0 \%$ & 0 & $30-52$ & Sangat & $30-52$ & 0 & $0 \%$ \\
\hline $\mathbf{1 0 0} \%$ & $\mathbf{3 4}$ & Jumlah & & & $\mathbf{3 5}$ & $\mathbf{1 0 0 \%}$ \\
\hline
\end{tabular}

Data post-test diberikan setelah pemberian treatment pada kelas eksperimen sedangkan kelas kontrol tidak mendapatkan treatment tetapi juga ikut diberikan post-test. Hasil post-test yang telah diperoleh dari kelas eksperimen dan kelas kontrol tentang tingkat kreativitas belajar menunjukkan bahwa kelas kontrol memiliki skor kelas interval 30 - 52 sebanyak 0 siswa dengan presentase $0 \%$ dalam kategori Sangat Rendah, pada kelas eksperimen dan kontrol menunjukkan bahwa memiliki skor kelas interval 53 - 75 dalam kategori rendah sebanyak 56 siswa dengan presentase $21 \%$ dalam kelas eksperimen dan 7 siswa dalam kelas kontrol, sedangkan pada kelas skor interval 76 - 98 kategori tinggi dengan presentase $83 \%$ dan $79 \%$, kelas eksperimen 29 siswa dan kelas kontrol 27. Dan untuk kelas eskperimen dan kelas kontrol skor kelas 99 - 120 kategori sangat tinggi presentase $6 \%$ pada kelas eksperimen 2 siswa dan kelas kontrol 0 siswa. Selengkapnya dapat dilihat dalam grafik batang berikut ini :

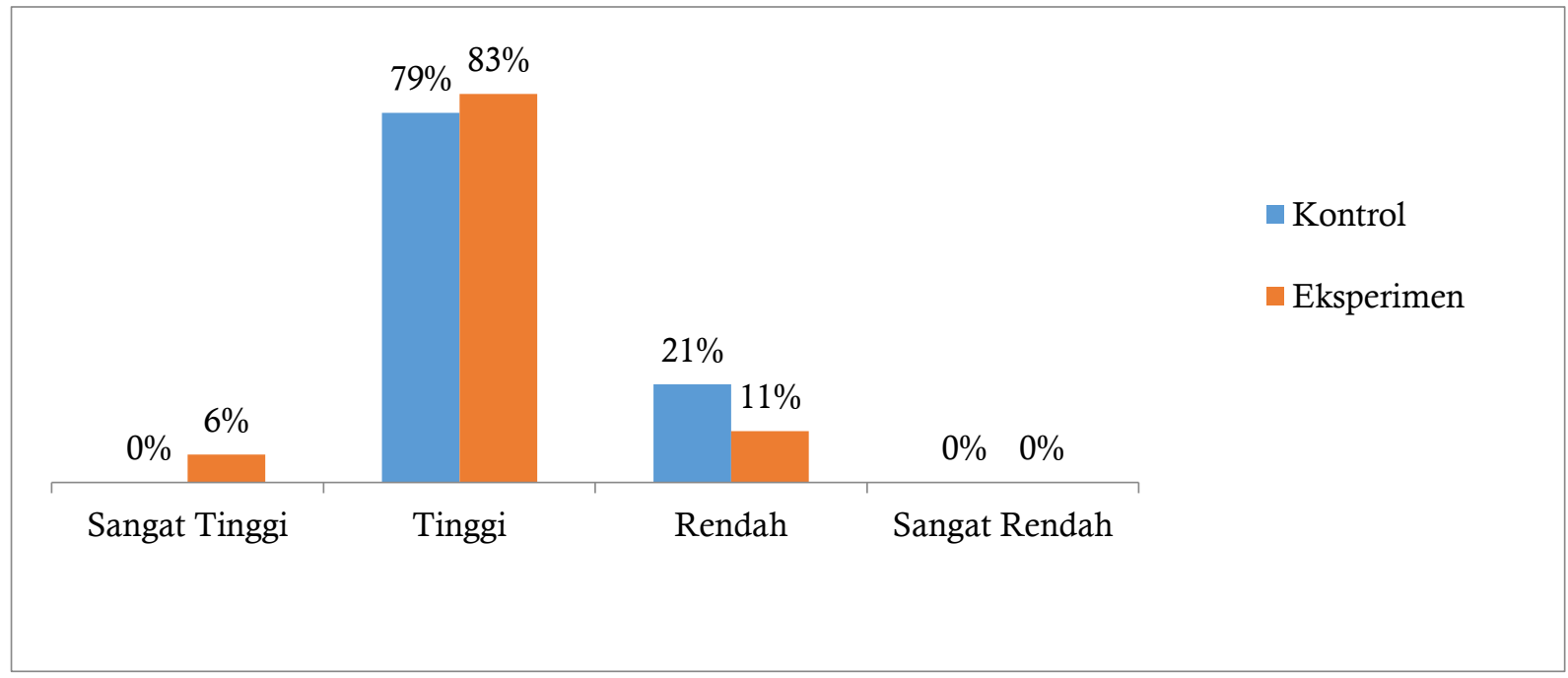

Grafik 1. Hasil Post-test Kreativitas Belajar

Berdasarkan hasil analisis tingkat kreativitas belajar sebelum diberikan perlakuan (pre-test) pada kelompok eksperimen dan setelah diberikan perlakuan (post-test) terdapat perbedaan. Berdasarkan data yang diperoleh hasil klarifikasi prosentase setelah mendapat layanan informasi dengan media audio visual lebih tinggi dibanding dengan klasifikasi prosentase sebelum diberikan treatment atau perlakuan. Hal ini menunjukkan bahwa layanan informasi dengan media audio visual memberikan pengaruh yang positif terhadap kreativitas belajar siswa. Selengkapnya dapat dilihat dalam grafik batang berikut perbedaan rata-rata pre-test dan post-test: 


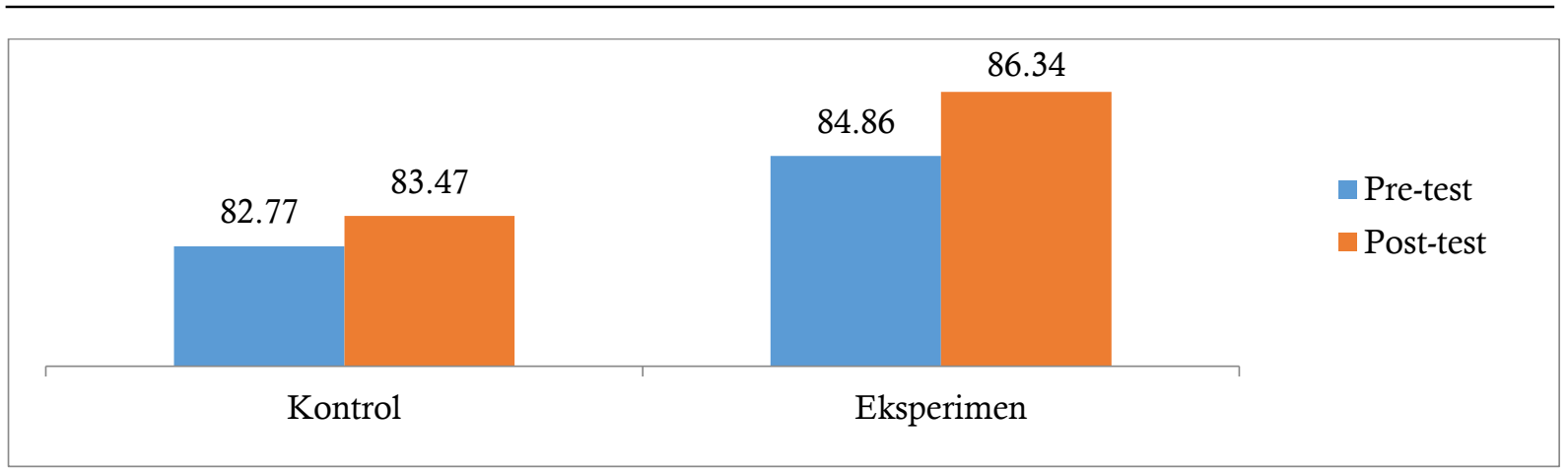

Grafik 2. Selisih Rata-rata Hasil Pre-test dan Post-test

Hasil analisis data pre-test kelompok kontrol dengan siswa 34 jumlah 2814 dan rata-rata 82,76 dan kelompok eksperimen dengan siswa 35 jumlah 2970 dan rata-rata 84,86.

Berdasarkan Uji-t diperoleh $t_{\text {hitung }}$ sebesar 2,63 sementara $t_{\text {tabel }}$ dengan $d b(n 1+n 2)-2=30$ dan taraf signifikan 5\% sebesar 2,04 (lihat tabel $t$ ). Karena $t_{\text {hitung }}>t_{\text {tabel }}$ yakni 2,94> 2,00 maka dapat disimpulkan bahwa tidak terdapat perbedaan tingkat kreativitas belajar siswa antara kelompok eksperimen pre-test. Adapun analisis kedua yaitu untuk menguji hipotesis yang diajukan dalam hal ini adalah perbedaan antara hasil dari pretest - postest kelompok eksperimen. Hasil analisis data post-test kelompok kontrol dengan siswa 34 jumlah 2838 dan rata-rata 83,47 dan kelompok eksperimen dengan siswa 35 jumlah 3022 dan rata-rata 86.34

Berdasarkan Uji-t diperoleh $t_{\text {hitung }}$ sebesar 7,85 sementara $t_{\text {tabel }}$ dengan $d b(n 1+n 2)-2=30$ dan taraf signifikan 5\% sebesar 2,00 (lihat tabel t). Karena $t_{\text {hitung }}>t_{\text {tabel }}$ yakni 7,85 $>2,00$,maka dapat disimpulkan bahwa ada perbedaan tingkat kreativitas belajar pada kelas eksperimen setelah dibandingkan dengan perbedaan kelas eksperimen dan kelas kontrol. Jadi layanan informasi dengan menggunakan media audio visual berpengaruh terhadap kreativitas belajar siswa kelas XII SMA Kartika III-1 Banyubiru. Maka hipotesis kerja (Ha) yang berbunyi layanan informasi dengan media audio visual berpengaruh terhadap kreativitas belajar siswa kelas XII SMA Kartika III-1 Banyubiru diterima dengan taraf signifikan $0,05(5 \%)$.

Hasil penelitian didukung dengan Djamarah (2013: 124) media audio visual adalah media yang mempunyai unsur suara dan unsur gambar. Media audio visual ini mempunyai nilai tertentu yaitu dapat menarik dan memotivasi belajar siswa untuk mempelajari materi lebih banyak, memancing inspirasi baru dan penyajian lebih menarik karena mengandung nilai rekreasi.

Hasil penelitian ini diperkuat dengan pendapat Yusuf (2010: 16) yang menyatakan bahwa kreativitas belajar sebagai kemampuan untuk menciptakan sesuatu yang baru, sperti solusi untuk suatu masalah atau penampilan baru, nilai seni, atau metode baru. Berbagai referensi menunjukan bahwa kreativitas adalah konsep yang terdiri atas konsep-konsep ilmu psikologi kognitif. Menurut pendapat Munandar (2004: 51 ) yang menjelaskan siswa yang kreatif adalah siswa yang mempunyai rasa ingin tahu, tertarik terhadap tugas-tugas majemuk yang dirasakan sebagai tantangan, berani mengambil resiko dan tidak mudah putus asa dan lain sebagainya. Kreativitas belajar bertujuan agar siswa mampu membuat kombinasi baru berdasarkan data yang ada dan kreativitas sebagai daya cipta untuk menciptakan hal-hal baru. Kemampuan berdasarkan data atau informasi yang tersedia dan menemukan banyak jawaban terhadap suatu masalah (Nur' aeni, 2008: 4).

Layanan informasi dengan menggunakan media audio visual dilakukan sebanyak lima kali dengan topik rasa ingin tahu yang tinggi, rasa percaya diri, menghargai orang lain, menyatakan ide-ide baru dan mengatasi masalah yang rumit. Dengan menggunakan layanan informasi dengan menggunakan media audio visual diperoleh pada kelas eksperimen meningkat setelah dilakukan treatment. Hal ini disebabkan adanya perlakuan yang diberikan pada kelas eksperimen sedangkan kelas kontrol tidak mendapatkan perlakuan berupa layanan informasi menggunakan media audio visual.

Ketepatan penggunaan layanan informasi dengan metode menggunakan media audio sebagai salah satu layanan untuk membantu meningkatkan kreativitas belajar siswa kelas XII SMA Kartika III-1 Banyubiru. 


\section{Simpulan Dan Saran}

Berdasarkan hasil perhitungan penelitian analisis rumus T- test diperoleh hasil $\mathrm{T}_{\text {hitung }}$ sebesar 2,00 selanjutnya dikonsultasikan dengan $\mathrm{T}_{\text {tabel }}$ pada taraf signifikan dengan $\mathrm{N}=69$ yaitu sebesar $=$ 2.00, maka $\mathrm{T}_{\text {hitung }}>\mathrm{T}_{\text {tabel }}$ adalah 2,94>2,00. Atas dasar perhitungan tersebut maka hipotesis $\mathrm{Ha}$ diterima yang dinyatakan "layanan informasi dengan menggunakan media audio visual berpengaruh terhadap kreativitas belajar siswa kelas XII SMA Kartika III-1". Hipotesis Ha diterima pada taraf signifikan 5\%. Dengan demikan terdapat pengaruh layanan informasi dengan menggunakan media audio visual terhadap kreativitas belajar siswa kelas XII SMA Kartika III-1.

Dalam meningkatkan kreativitas belajar siswa, menggunakan layanan informasi dengan menggunakan media audio visual memiliki beberapa kekurangan. Beberapa keterbatasan peneliti dalam pelaksanaan layanan yaitu waktu dalam pemberian layanan yang hanya 40 menit sehingga pemberian materi tidak maksimal. Dalam penelitian tidak semua kelas ada media untuk pemberian materi sehingga harus membawa alat untuk penayangan medianya.

Begitu pula dengan isi dari hasil penelitian yang dipaparkan oleh peneliti karena penelitian ini menggunakan kuantitatif sehingga peneliti tidak dapat mengali informasi lebih lanjut dan mendalam mengenai penyebab-penyebab rendahnya kreativitas belajar siswa, serta teknik pengumpulan data hanya menggunakan skala kreativitas belajar sehingga data-data yang lain tidak dapat terjaring lebih luas dan lengkap. Karena dalam pembagian kelas menggunakan sistem kesetaraan antara kelas eksperimen dan kelas kontrol sehingga ada selisih sedikit dari hasil penelitian yang dilakukan, namun dari pihak peneliti menggusahakan untuk kesetaraan dari berbagai hal. Generalisasi dalam penelitian ini terbatas pada populasinya yaitu siswa kelas XII SMA Kartika III-1, kalau pada populasi lain harus dilakukan penelitian sejenis. Akan tetapi, hal tersebut tidak menjadi kendala bagi peneliti karena banyak pihak dalam menyelesaikan penelitian ini sehingga diharapkan dapat bermanfaat bagi banyak kalangan pula. Layanan informasi dengan menggunakan media audio visual juga dapat menambah pengetahuan bagi guru BK dan menjadi hal menarik untuk siswa.

Oleh karena itu kreativitas harus dimiliki siswa untuk menghasilkan ide-ide baru yang bisa digunakan dalam proses pembelajaran. Salah satu faktor yang mempengaruhi hasil belajar adalah kreativitas belajar karena kreativitas merupakan kemampuan mengimajinasikan, menafsirkan dan mengemukakan gagasan serta usaha yang memiliki daya cipta untuk kombinasi baru dari unsur sebelumnya yang sudah ada sehingga dieroleh peningkatan kualitas siswa dalam pengembangan drinya (Putri T, 2013: 3).

Kreativitas belajar sangat penting dimiliki oleh siswa dalam proses pembelajarannya karena dapat menciptakan hal-hal yang baru sehingga hasil belajar yang diperoleh pun akan memuaskan. Jika siswa tidak mempunyai kreativitas akan susah dalam proses pembelajaranya karena tidak bisa menghasilkan yang baru untuk proses belajar sehingga hasil belajarnya pun tidak sesuai yang diharapkan. Tapi faktor siswa tidak bisa kreatif juga bisa disebabkan guru yang mengajarnya tidak memberikan siswa untuk mengembangkan kreativitasnya sehingga siswa pun hanya bisa mendengarkan apa yang diberikan oleh guru tersebut dan tidak bisa memberikan gagasan-gagasan atau ide-ide yang dimiliki oleh siswa.

\section{Daftar Rujukan}

Arikunto, Suharsami. 2010. Prosedur Penelitian Suatu Pendekatan Praktik. Jakarta: Rineka Cipta

Arsyad, Azhar. 2007. Media Pembelajaran. Jakarta. PT. RajaGrafindo Persada

Budiningsih, Asri. 2005. Belajar dan Pembelajaran. Jakarta. Rineka Cipta

Djamarah, Syaiful Bahri dan Zain, Aswan. 2013. Strategi Belajar Mengajar. Jakarta. Rineka Cipta.

Kustandi, Cecep dan Sutjipto, Bambang. 2011. Media Pembelajaran Manual dan Digital. Bogor. Ghalia Indonesia. 
Munandar, Utami. 2004. Pengembangan Kreativitas Anak Berbakat. Jakarta: Rineka Cipta.

Munandar, Utami. 2009. Pengembangan Kreativitas Anak Berbakat. Jakarta. Rineka Cipta.

Muniarti, Endyah. 2012. Pendidikan dan Bimbingan Anak Kreatif.Jurnal Pendidikan. Yogyakarta.Pedagogia.

Nur'aeni.2008. Ada Apa Dengan Kreatifitas?.Jurnal Psikologi.Vol.VII. No.3. Hal : 20.

Nursalim, Muchamad. 2013. Pengembangan Media Bimbingandan Konseling. Jakarta. @kademia.

Peraturan Menteri Pendidikan Nasional Republik Indonesia Nomor 23 Tahun 2006 tentang. Standar Kompetensi Lulusan, Jakarta, 2006.

Prayitno, dan Amti Erman. 2013. Dasar Dasar Bimbingan dan Konseling. Jakarta. PT.Rineka Cipta.

Prayitno. 2004. Bimbingan dan Konseling .Padang: Universitas Negeri Padang.

Setiyani, Ade Irma, Susilo, dan Jaino. 2013. Peningkatan Kualitas PembelajaranIPS Menggunakan Snowball ThrowingMedia Audio visual Kelas IV. Jurnal Unnes Vol.2 No. $3: 72$. Hal :18.

Soegeng, Ysh. 2006. Dasar-dasar Penelitian Bidang Sosial, Psikologi, dan Pendidikan. Semarang : IKIP PGRI Semarang Press.

Sugiyono. 2012. Metode Penelitian Pendidikan. Bandung. Alfabeta

Sukardi, Dewa Ketut. 2008. Pengantar Program Bimbingan Dan Konseling di Sekolah. Jakarta. PT. Rineka Cipta.

Sukarno, Anton \& Venty. 2008. Statistik Lanjut. Surakarta : Universitas Sebelas Maret.

Suryabrata, Sumardi. 2013. Metodologi Penelitian Jakarta : Rajawali Pers.

Tirtiana, Chandra Putri. 2013. Pengaruh Kreatifitas Belajar Penggunanaan Pembelajaran Power Point. Jurnal Pendidikan. Vol. 2 No.2 :16. Hal 16.

Winkel, dan Hastuti. 2004. Bimbingan dan Konseling di Institut Pendidikan. Yogyakarta. Media Abadi.

Yusuf, Syamsu. 2010. Program Bimbingan dan Konseling di Sekolah. Bandung :Rizqi Press.

Zuldafrial. 2012. Strategi Belajar Mengajar. Surakarta. Cakrawala Media 